\title{
AC 2008-847: THE ATTITUDES AND OPINIONS OF STUDENTS TOWARD TECHNICAL GRAPHICS: PRELIMINARY SURVEY RESULTS
}

\section{Aaron Clark, North Carolina State University}

Aaron C. Clark is an Associate Professor of Graphic Communications at North Carolina State University in Raleigh. He received his B.S. and M.S. in Technology and Technology Education from East Tennessee State University. He earned his doctoral degree from North Carolina State University. His teaching specialty is in introductory engineering drawing, with emphasis in 3D modeling and animation. His research areas include graphics education and scientific/technical visualization. He presents and publishes in both vocational/technology education and engineering education. Contact Info: (919)515-1771 aaron_clark@ncsu.edu

\section{Jeremy Ernst, North Carolina State University} Jeremy V. Ernst is a Visiting Assistant Professor in the Mathematics, Science, and Technology Education Department at North Carolina State University. He received a B.S. in Technology and Human Resource Development from Clemson University, and a M.Ed. in Technology Education from North Carolina State University where he completed his doctoral degree in Technology Education. His research interests are in effective instruction and special education. Contact Info: (919)515-1741 jeremy_ernst@ncsu.edu

\section{Alice Scales, North Carolina State University}

Alice Y. Scales is the Assistant Department Head of the Department of Mathematics, Science, and Technology Education and Coordinator of the Graphic Communications Program at North Carolina State University. She has taught at North Carolina State University since 1988. She has a B.S. in Science Education, a M.Ed. in Industrial Arts Education, and an Ed.D. in Occupational Education. At NC State University, she teaches introductory engineering graphics courses that include CAD, desktop publishing, and web site development. 


\title{
THE ATTITUDES AND OPINIONS OF STUDENTS TOWARD TECHNICAL GRAPHICS: PRELIMINARY SURVEY RESULTS
}

\begin{abstract}
In the fall semester of 2007, students in introductory engineering graphics courses at North Carolina State University (NCSU) were given a survey to examine their attitudes and opinions concerning the usefulness of technical graphics in their personal and future professional life as well as the types of strategies they use when solving graphics problems. This survey will provide the Graphic Communications Program at NCSU with a snapshot of the ways in which their classes achieve and fail in their mission to teach graphic concepts, methodology, and an appreciation of the function of graphics in professional and personal day-to-day experiences. These courses attract a variety of majors, with engineering disciplines representing the majority. The survey was based on the Colorado Learning Attitudes about Science Survey (CLASS) and adapted for use in graphic communications. The preliminary analysis of the data will be presented in this paper along with some interpretation of the results.
\end{abstract}

\section{Introduction}

Student interests and beliefs are integral components of curricular and instructional practices in engineering education. Inventorying student interests and beliefs assists in the creation of logical instructional clusters that are appealing to specific student groups ${ }^{1}$. A mounting body of research on adult learners suggests that increased learning gains can be attained when instruction is presented in an appealing manner and is designed with students' learning styles in mind ${ }^{2}$. Engaging students' interests increases their motivation to learn and promotes deeper understandings of content ${ }^{3}$. Educators strive not only to increase student knowledge, but also to motivate students to gain an appreciation for what they are learning. If instruction motivates students then they are likely to value their educational endeavors and perhaps even seek like educational experiences in the future ${ }^{4}$.

Educational psychologists have conducted extensive research on student interest and motivation across disciplines ${ }^{5}$. One targeted group is students enrolled in introductory science courses at the postsecondary level. Student interests and beliefs associated with science has been an active area of research over the past decade ${ }^{6}$. One objective of postsecondary education is to convey information and skills of practical value to students. It is relatively easy to assess the imparting of knowledge, but what students believe, appreciate, value, and will be receptive to is not as easily assessable ${ }^{7}$. Recently, the Colorado Learning Attitudes about Science Survey (CLASS) has been used to measure student beliefs. Many of these studies utilizing the CLASS instrument relied on a study design using students enrolled in introductory physics and chemistry courses. The common use of the CLASS instrument is attributed to the many useful ways to analyze and use its data ${ }^{8}$. 
This research study builds on prior efforts but is structured to provide insight into engineering student interests and beliefs by using a modified version of the CLASS instrument.

\section{Methodology:}

The survey instrument used in this study was an adaptation of the CLASS survey. Developed at the University of Colorado, the questions on the CLASS survey were "designed to measure student beliefs about physics and about learning physics"1. The CLASS instrument has undergone a rigorous validation and reliability process. The validation process included faculty and student interviews for face validity, a factor analysis after administering the survey to several thousand students for construct validity, correlation of incoming students beliefs for predictive validity, and analysis of survey responses for concurrent validity ${ }^{1}$.

Using this instrument as the template, the statements were rewritten to produce a similar survey for examining the attitudes of students towards engineering graphics and learning engineering graphics, in a similar way in which the CLASS survey has been also been adapted for courses in Geology at the University of Colorado.

The original survey was composed of 42 statements, which respondents rate on a five point Likert scale. The Likert scale utilized a range from one (1) "Strongly Agree" to five (5) "Strongly Disagree." The graphics version, know as the "North Carolina Learning Attitudes about Graphics Education Survey" (NCLAGES), consist of 43 statements as well as demographic questions. Examples of statements used on the NCLAGES include:

1. "It is useful for me to do lots and lots of problems when learning graphics."

2. "Learning graphics changes my ideas about how the world works."

3. "In graphics, it is important for me to make sense out of engineering and design concepts before I can use them correctly."

Seven randomly selected sections of GC 120, Foundations of Graphics, were used in the study at NC State University. GC 120 is an introductory course designed to teach the fundamentals of engineering/technical graphics. The course is listed on the university's general education requirements as an elective under the Visual and Performing Arts category; therefore, it attracts both engineering and non-engineering majors, although the majority of students taking these are engineering majors or in some technical field. Each section of the course consisted of 24 students and is taught over 15 weeks. GC 120 includes instruction in SolidWorks 3D modeling software as well as basic instruction in the concepts of engineering drawing, including sketching, geometric construction, isometric drawings, multiviews, auxiliaries, sections, dimensioning, and working drawings. Most of the sections meet two days a week for 110-minute a sessions, the exception to this were two sections included in the study that meet one night a week for four hours. 
The classes were given the survey during the $13^{\text {th }}$ week of class out of a 15 week semester, which allowed the students to have the benefit of the majority of the course before completing the survey. The information was then compiled and the preliminary results are given below.

\section{Demographic Findings}

Of those students that correctly completed the NCLAGES survey, 161 were useful and analyzed for this study. Demographic information collected from the survey provided the following information. The majority of the participants, 87 (54\%), were between the ages of 18-19, while $59(37 \%)$ were between 20-21 years of age (see table 1). Of the students who were included in the survey, the majority, 109 students or $68 \%$, were sophomores. The students were predominately Caucasian, with 142 or $88 \%$ falling into this category. Most of the study participants, 138 (86\%), were also male. Fifty-one of the students were majoring in mechanical engineering, and 35 were majoring in civil engineering. Other majors included 22 in aerospace engineering, and nine in technology education/graphic communication. Eighteen (11\%) were transfer students from another college or university, and 59 (37\%) had previous taken a technical graphics course in high school or college before taking GC 120 (see Table 1). One specialized question asked of student participants involved their interest in completing a fifth year of college to receive a teacher license in either technology education or graphic communications so that they could teach at the high school or college level. Twenty-seven (17\%) indicated they would be interested in this to diverse their future employment options.

Table 1

\begin{tabular}{|c|c|c|c|c|}
\hline Age & Class & Race & $\begin{array}{c}\text { Anticipated } \\
\text { Grade }\end{array}$ & $\begin{array}{c}\text { Preferred } \\
\text { Learning Style }\end{array}$ \\
\hline $\begin{array}{c}17 \text { or less } \\
0 / 0 \%\end{array}$ & $\begin{array}{c}\text { Freshman } \\
4 / 2 \%\end{array}$ & $\begin{array}{c}\text { Caucasian } \\
142 / 88 \%\end{array}$ & $\begin{array}{c}\mathrm{A} \\
82 / 51 \%\end{array}$ & $\begin{array}{c}\text { Auditory } \\
6 / 4 \%\end{array}$ \\
\hline $\begin{array}{c}18-19 \\
87 / 54 \%\end{array}$ & $\begin{array}{c}\text { Sophomore } \\
109 / 68 \%\end{array}$ & $\begin{array}{c}\text { African-Am. } \\
9 / 7 \%\end{array}$ & $\begin{array}{c}\mathrm{B} \\
72 / 45 \%\end{array}$ & $\begin{array}{c}\text { Visual } \\
94 / 58 \%\end{array}$ \\
\hline $\begin{array}{c}20-21 \\
59 / 37 \%\end{array}$ & $\begin{array}{c}\text { Junior } \\
32 / 20 \%\end{array}$ & $\begin{array}{l}\text { Asian } \\
4 / 2 \%\end{array}$ & $\begin{array}{c}\mathrm{C} \\
7 / 4 \%\end{array}$ & $\begin{array}{c}\text { Reading } \\
2 / 1 \%\end{array}$ \\
\hline $\begin{array}{l}22-24 \\
8 / 5 \%\end{array}$ & $\begin{array}{c}\text { Senior } \\
16 / 10 \%\end{array}$ & $\begin{array}{c}\text { Hispanic } \\
2 / 1 \%\end{array}$ & $\begin{array}{c}\mathrm{D} \\
0 / 0 \%\end{array}$ & $\begin{array}{c}\text { Written } \\
2 / 1 \%\end{array}$ \\
\hline $\begin{array}{c}24 \text { or greater } \\
7 / 4 \%\end{array}$ & $\begin{array}{l}\text { Other } \\
0 / 0 \%\end{array}$ & $\begin{array}{c}\text { Native Am. } \\
2 / 1 \%\end{array}$ & $\begin{array}{c}\mathrm{F} \\
0 / 0 \%\end{array}$ & $\begin{array}{c}\text { Multi-modal } \\
57 / 36 \%\end{array}$ \\
\hline & & $\begin{array}{l}\text { Other } \\
2 / 1 \%\end{array}$ & $\begin{array}{c}\mathrm{S} / \mathrm{U} \\
0 / 0 \%\end{array}$ & \\
\hline
\end{tabular}

The NCLAGES survey asked students their anticipated final grade in the course as of the $13^{\text {th }}$ week of class. Eighty-two or $51 \%$ of the participants indicated an A, 72 or $45 \%$ a B, while seven 
or four percent a $\mathrm{C}$. None of the participants felt they would receive a grade of D or $\mathrm{F}$. They were also asked what they thought was their preferred learning style and were allowed to select more than one style from the categories of auditory, visual, reading, and written. Most students, 94 or $58 \%$, choose visual as their preferred learning style. The next highest frequency was multimodal, where student choose at least two or more of the given learning styles, with 57 students or $36 \%$ indicating a combination of learning preferences. Six students or $4 \%$ thought they learned best auditory, and both reading and written categories had 2 students, or 1\%, selecting these as their preferred learning style (see Table 1).

Students were asked to list their favorite hobbies as well as how they see using the course's content in the future. Table 2 shows the most common responses to these write-in questions.

Table 2

\begin{tabular}{|c|c|}
\hline $\begin{array}{l}\text { avorite Hobbies: } \\
\text { laying sports } \\
\text { ishing, golfing, all sports, mountain } \\
\text { iking } \\
\text { ports, cars } \\
\text { iding horses, working outside, video } \\
\text { rames, friends } \\
\text { eading, watching TV and movies, } \\
\text { aintball } \\
\text { Music } \\
\text { kuitar, video games, art } \\
\text { kate boarding, shopping, etc. } \\
\text { lunting, shooting, sports, } \\
\text { laying music, listening to music, } \\
\text { aseball, basketball } \\
\text { ports and video games } \\
\text { ltimate Frisbee, surfing, soccer } \\
\text { RC aircraft, Wikipedia, reading, } \\
\text { landcrafts, sewing } \\
\text { ideo games } \\
\text { occer, ultimate, football, running, } \\
\text { asketball }\end{array}$ & $\begin{array}{l}\text { Using Course Content in Future: } \\
\text { To not only help see things on a more visual basis } \\
\text { but hopefully to have a better background so as to } \\
\text { be able to use graphics programs to develop ideas } \\
\text { for any technical or visual presentation } \\
\text { I might have in the future using engineering } \\
\text { drawings and CAD experience to design } \\
\text { mechanical parts } \\
\text { Designing aircraft or spacecraft, modeling } \\
\text { imbedded systems as a basis for other classes } \\
\text { I see it being a very big part of my engineering } \\
\text { future for rapid prototyping of parts } \\
\text { Using techniques learned for visual communication } \\
\text { In the development of ideas and in engineering } \\
\text { projects } \\
\text { To be able to build any product needed by a } \\
\text { company } \\
\text { Understanding graphics communication is useful in } \\
\text { explaining systems } \\
\text { Using it in my co-op }\end{array}$ \\
\hline
\end{tabular}




\section{Survey Results}

As stated earlier, there were 161 completed and returned NCLAGES surveys that provided usable data for analysis. On this survey, students were asked to rate each of the 43 statements using a Likert scale from one to five to express their closest feeling about a given statement. The Likert scale categories were: 1. Strongly Disagree, 2. Disagree, 3. Neutral, 4. Agree, 5. Strongly Agree. If they did not understand a statement, students could leave it blank.

In the original CLASS survey, statements comprised nine categories of content that were defined and described by Adams et al. ${ }^{1}$. Adams' categories summarize the statements in a category, but survey participants were not made aware of the groupings. In the NCLAGES study, the researchers followed the same procedure, with students not being made aware of the statements groupings. The new survey used names and definitions similar to the original instrument but took the liberty of changing them to suite the content of the course surveyed and the type of students enrolled in it. The NCLAGES category labels and definitions are: Group 1: Real world relations — describes how students relate information to scenarios; Group 2: Personal Interest - defines students' interests in areas of visualization and graphics; Group 3: Sense Making — indicates if students really understand the usefulness of the materials being studied; Group 4: Conceptual Associations-demonstrates the way student relate to materials and make comparisons; Group 5: Applied Understanding — describes how students could apply content in and beyond the classroom environment; Group 6: Problem Solving — describes how students use the content presented in class to solve general and basic problems related to graphics; Group 7: Confidence in Problem Solving - shows if students are comfortable using the information from the course; Group 8: Advanced Problem Solving — demonstrates the use of higher-order thinking skills in relationship to content covered in the course; Group 9: General Attitudes — provides information concerning students' overall feelings towards a course of this type. Note that the categories and definitions are the interpretations and working definitions of the authors of this study only, inferences made from other studies that used the original CLASS survey were only referenced for the classification, labeling, and definition development for the data collected from this survey instrument. Also, question 31, which stated "We can use this statement to discard the survey of people who are not reading the statements. Please select agree-option 4 (not strongly agree) for this statement," was used as a control statement. This statement was part of the original survey and was used to control for participants not taking the survey seriously; therefore, if the response to this statement was not a four (4) on a participant's survey, it was discarded from the analyzed data for this study. In this study sixteen instruments were eliminated by the responses to the control statement. The overall mean for this question was 3.89 with a standard deviation (SD) of . 38 and a mode of 4 ; therefore, it was concluded by the researchers of this study that the majority of students took the time to read and respond to the statements.

The tables below list each of the categories with their corresponding group of statements. Please note that many of the statements were used in more than one category and grouping. These statements were repeated to help the reader draw conclusions from the grouping of a like content 
from the statements as they relate to corresponding categories. Each table for its designated group or category will provide related statements with the average of the Likert score, mode showing the most common selected Likert rating, and the standard deviation for each statement.

Table 3

Group 1: Real world relations — describes how students relate information to scenarios.

\begin{tabular}{|l|l|c|c|}
\hline NCLAGES Statement & Mean & Mode & SD \\
\hline Learning graphics changes my ideas about how the world works. & 3.10 & 3 & 1.06 \\
\hline $\begin{array}{l}\text { The subject of graphics has little relation to what I experience in the real } \\
\text { world. }\end{array}$ & 2.48 & 2 & .98 \\
\hline $\begin{array}{l}\text { To understand graphics, I sometimes think about my personal } \\
\text { experiences and relate them to the topic being analyzed. }\end{array}$ & 2.82 & 3 & .96 \\
\hline $\begin{array}{l}\text { Reasoning skills used to understand graphics can be helpful to me in my } \\
\text { everyday life. }\end{array}$ & 3.66 & 4 & .89 \\
\hline
\end{tabular}

Table 4

Group 2: Personal Interest — defines students' interests in areas of visualization and graphics.

\begin{tabular}{|l|l|r|r|}
\hline NCLAGES Statement & Mean & Mode & SD \\
\hline I think about the graphics I experience in everyday life. & 3.09 & 3 & 1.11 \\
\hline $\begin{array}{l}\text { I am not satisfied until I understand why something works the way it } \\
\text { does. }\end{array}$ & 3.95 & 4 & .84 \\
\hline $\begin{array}{l}\text { I study graphics to learn knowledge that will be useful in my life } \\
\text { outside of school. }\end{array}$ & 3.57 & 4 & 1.06 \\
\hline I enjoy solving graphics based problems. & 3.61 & 4 & 1.03 \\
\hline Learning graphics changes my ideas about how the world works. & 3.10 & 3 & 1.06 \\
\hline $\begin{array}{l}\text { Reasoning skills used to understand graphics can be helpful to me in my } \\
\text { everyday life. }\end{array}$ & 3.66 & 4 & .89 \\
\hline
\end{tabular}




\section{Table 5}

Group 3: Sense Making - indicates if students really understand the usefulness of the materials being studied.

\begin{tabular}{|l|l|r|r|}
\hline NCLAGES Statement & Mean & Mode & SD \\
\hline $\begin{array}{l}\text { I am not satisfied until I understand why something works the way it } \\
\text { does. }\end{array}$ & 3.95 & 4 & .84 \\
\hline $\begin{array}{l}\text { In doing a graphic-based problem, if my method gives a result very } \\
\text { different from what I'd expect, I'd trust the calculation rather than going } \\
\text { back through the problem. }\end{array}$ & 2.3 & 2 & .98 \\
\hline $\begin{array}{l}\text { In graphics, it is important for me to make sense out of engineering and } \\
\text { design concepts before I can use them correctly. }\end{array}$ & 3.70 & 4 & .88 \\
\hline $\begin{array}{l}\text { Spending a lot of time understanding where graphic concepts come from } \\
\text { is a waste of time. }\end{array}$ & 2.53 & 2 & .93 \\
\hline $\begin{array}{l}\text { There are times I solve a graphic problem more than one way to help my } \\
\text { understanding. }\end{array}$ & 2.99 & 4 & 1.05 \\
\hline $\begin{array}{l}\text { When I solve a graphic problem, I explicitly think about which design } \\
\text { method to apply to the problem. }\end{array}$ & 3.44 & 4 & .90 \\
\hline $\begin{array}{l}\text { When studying graphics, I relate the important information to what I } \\
\text { already know rather than just memorizing it the way it is presented. }\end{array}$ & 3.67 & 4 & .76 \\
\hline
\end{tabular}

Table 6

Group 4: Conceptual associations-demonstrates the way student relate to materials and make comparisons.

\begin{tabular}{|l|c|c|c|}
\hline NCLAGES Statement & Mean & Mode & SD \\
\hline $\begin{array}{l}\text { A significant problem in learning technical graphics is being able to } \\
\text { memorize all the information I need to know. }\end{array}$ & 2.84 & 2 & 1.10 \\
\hline $\begin{array}{l}\text { After I study a topic in graphics and feel that I understand it, I have } \\
\text { difficulty solving problems on the same topic. }\end{array}$ & 2.1 & 2 & .98 \\
\hline Knowledge in graphics consists of many disconnected topics. & 2.27 & 2 & .89 \\
\hline $\begin{array}{l}\text { I do not expect graphic and design concepts to help my understanding } \\
\text { of the ideas; they are just for doing working drawings. }\end{array}$ & 2.21 & 2 & .94 \\
\hline $\begin{array}{l}\text { If I don't remember a particular strategy needed to solve a problem on } \\
\text { an exam, there's nothing much I can do ethically to come up with it. }\end{array}$ & 2.55 & 2 & .98 \\
\hline $\begin{array}{l}\text { Spending a lot of time understanding where graphic concepts come } \\
\text { from is a waste of time. }\end{array}$ & 2.53 & 2 & .93 \\
\hline
\end{tabular}


Table 7

Group 5: Applied understanding — describes how students could apply content in and beyond the classroom environment.

\begin{tabular}{|l|c|r|r|}
\hline NCLAGES Statement & Mean & Mode & SD \\
\hline $\begin{array}{l}\text { A significant problem in learning technical graphics is being able to } \\
\text { memorize all the information I need to know. }\end{array}$ & 2.84 & 2 & 1.10 \\
\hline $\begin{array}{l}\text { After I study a topic in graphics and feel that I understand it, I have } \\
\text { difficulty solving problems on the same topic. }\end{array}$ & 2.1 & 2 & .98 \\
\hline Knowledge in graphics consists of many disconnected topics. & 2.27 & 2 & .89 \\
\hline $\begin{array}{l}\text { When I solve a graphics problem, I locate an example that uses the } \\
\text { variables given in the problem and reference the example. }\end{array}$ & 3.26 & 4 & 1.04 \\
\hline $\begin{array}{l}\text { If I don't remember a particular strategy needed to solve a problem on } \\
\text { an exam, there's nothing much I can do ethically to come up with it. }\end{array}$ & 2.55 & 2 & .98 \\
\hline $\begin{array}{l}\text { If you want to apply method used for solving one graphic problem to } \\
\text { another problem, the problems must involve very similar situations. }\end{array}$ & 2.84 & 3 & .87 \\
\hline $\begin{array}{l}\text { If I get stuck on a graphic problem, there is no chance I'll figure it out } \\
\text { on my own. }\end{array}$ & 1.79 & 2 & .85 \\
\hline
\end{tabular}

Table 8

Group 6: Problem solving — describes how students use the content presented in class to solve general and basic problems related to graphics.

\begin{tabular}{|l|l|r|r|}
\hline NCLAGES Statement & Mean & Mode & SD \\
\hline $\begin{array}{l}\text { I do not expect graphic and design concepts to help my understanding of } \\
\text { the ideas; they are just for doing working drawings. }\end{array}$ & 2.21 & 2 & .94 \\
\hline $\begin{array}{l}\text { If I get stuck on a graphic problem my first try, I usually try to figure out } \\
\text { a different way that works. }\end{array}$ & 4.09 & 4 & .69 \\
\hline Nearly everyone is capable of understanding graphics if they work at it. & 4.04 & 4 & .87 \\
\hline I enjoy solving graphics based problems. & 3.61 & 4 & 1.03 \\
\hline $\begin{array}{l}\text { It is important to have governmental approval for technical graphics } \\
\text { standards. }\end{array}$ & 3.43 & 3 & 1.10 \\
\hline I can usually figure out a way to solve graphic problems. & 4.08 & 4 & .68 \\
\hline $\begin{array}{l}\text { If I get stuck on a graphic problem, there is no chance I'll figure it out } \\
\text { on my own. }\end{array}$ & 1.79 & 2 & .85 \\
\hline $\begin{array}{l}\text { When I am trying to solve a physical construction problem, I use } \\
\text { sketching it to visualize and solve the problem. }\end{array}$ & 3.73 & 4 & .95 \\
\hline
\end{tabular}


Table 9

Group 7: Confidence in problem solving — shows if students are comfortable using the information from the course.

\begin{tabular}{|l|r|c|c|}
\hline NCLAGES Statement & Mean & Mode SD \\
\hline $\begin{array}{l}\text { If I get stuck on a graphic problem my first try, I usually try to figure out } \\
\text { a different way that works. }\end{array}$ & 4.09 & 4 & .69 \\
\hline Nearly everyone is capable of understanding graphics if they work at it. & 4.04 & 4 & .87 \\
\hline I can usually figure out a way to solve graphic problems. & 4.08 & 4 & .68 \\
\hline $\begin{array}{l}\text { If I get stuck on a graphic problem, there is no chance I'll figure it out on } \\
\text { my own. }\end{array}$ & 1.79 & 2 & .85 \\
\hline
\end{tabular}

Table 10

Group 8: Advanced problem solving — demonstrates the use of higher-order thinking skills in relationship to content covered in the course.

\begin{tabular}{|l|l|r|r|}
\hline NCLAGES Statement & \multicolumn{1}{c|}{ Mean } & Mode & SD \\
\hline $\begin{array}{l}\text { After I study a topic in graphics and feel that I understand it, I have } \\
\text { difficulty solving problems on the same topic. }\end{array}$ & 2.1 & .98 \\
\hline $\begin{array}{l}\text { If I don't remember a particular strategy needed to solve a problem on } \\
\text { an exam, there's nothing much I can do ethically to come up with it. }\end{array}$ & 2.55 & 2 & .98 \\
\hline $\begin{array}{l}\text { If you want to apply method used for solving one graphic problem to } \\
\text { another problem, the problems must involve very similar situations. }\end{array}$ & 2.84 & 3 & .87 \\
\hline I can usually figure out a way to solve graphic problems. & 4.08 & 4 & .68 \\
\hline $\begin{array}{l}\text { If I get stuck on a graphic problem, there is no chance I'll figure it out } \\
\text { on my own. }\end{array}$ & 1.79 & 2 & .85 \\
\hline I enjoy solving graphics based problems. & 3.61 & 4 & 1.03 \\
\hline
\end{tabular}


Table 11

Group 9: General attitudes — provides information concerning students' overall feelings towards a course of this type.

\begin{tabular}{|c|c|c|c|}
\hline NCLAGES Statement & Mean & Mode & SD \\
\hline $\begin{array}{l}\text { When I am solving a graphics problem, I try to decide what would be a } \\
\text { reasonable solution to the answer. }\end{array}$ & 4.26 & 4 & .74 \\
\hline $\begin{array}{l}\text { It is useful for me to do lots and lots of problems when learning } \\
\text { graphics. }\end{array}$ & 3.15 & 4 & 1.15 \\
\hline $\begin{array}{l}\text { As graphic professionals learn more, most technology-based ideas we } \\
\text { use are likely to be proven wrong or become outdated. }\end{array}$ & 2.96 & 3 & 1.03 \\
\hline $\begin{array}{l}\text { I find that reading the text in detail is a good way for me to learn } \\
\text { graphics. }\end{array}$ & 2.29 & 2 & 1.07 \\
\hline $\begin{array}{l}\text { There is usually only one correct approach to solving a graphic } \\
\text { problem. }\end{array}$ & 1.90 & 1 & .99 \\
\hline $\begin{array}{l}\text { I cannot learn graphics if the teacher does not explain things well in } \\
\text { class. }\end{array}$ & 3.57 & 4 & 1.04 \\
\hline $\begin{array}{l}\text { Understanding graphics basically means being able to recall something } \\
\text { you've read or been shown. }\end{array}$ & 2.89 & 2 & 1.08 \\
\hline $\begin{array}{l}\text { There could be two different correct values to a graphic problem if I use } \\
\text { two different approaches. }\end{array}$ & 3.46 & 4 & 1.13 \\
\hline To understand graphic I discuss it with friends and other students. & 2.80 & 2 & 1.17 \\
\hline $\begin{array}{l}\text { I do not spend more than five minutes stuck on a graphic problem } \\
\text { before giving up or seeking help from someone else. }\end{array}$ & 2.16 & 2 & 1.0 \\
\hline $\begin{array}{l}\text { In graphics, geometric constructs express meaningful relationships that } \\
\text { allow me to understand whether or not a drawing is done correctly. }\end{array}$ & 3.89 & 4 & .70 \\
\hline $\begin{array}{l}\text { To learn graphics, I only need to memorize solutions to sample } \\
\text { problems. }\end{array}$ & 1.96 & 2 & .86 \\
\hline $\begin{array}{l}\text { I find carefully analyzing only a few problems in detail is a good way } \\
\text { for me to learn graphics. }\end{array}$ & 3.17 & 4 & .96 \\
\hline $\begin{array}{l}\text { It is possible to explain graphics-based ideas without using geometric } \\
\text { concepts. }\end{array}$ & 2.43 & 2 & 1.01 \\
\hline $\begin{array}{l}\text { It is possible for graphic professionals to carefully create the same } \\
\text { model and get two very different results that are both correct. }\end{array}$ & 3.30 & 4 & 1.10 \\
\hline
\end{tabular}

\section{Conclusions and Recommendations}

The population for this study mainly consisted of students majoring in engineering with $91 \%$ of the age range being between 18 and 21 . Students in the study were primarily sophomores and 
most considered themselves to be visual $(58 \%)$ or multi-modal $(36 \%)$ learners. After a careful review of the favorite hobbies listed by each of the student participants, the majority of these were visual in nature, consisting of two-dimensional (i.e. games) and three-dimensional (i.e. baseball, soccer) environments. Overall, most of the student participants indicated they felt the content covered in the course would be useful in their future job or career. This is a notable finding, since the course is listed as a visual and performing arts elective on the general education course lists for all majors at NC State University. Likewise, about 20 percent considered some day teaching technology and graphics education as a career. This is important as public education works to improve the content taught to students so that the country can remain competitive on a global scale.

As indicated by the high Likert mean and mode for the real-world relations, students see how the content covered in the course could be used beyond the course, and they appreciated the handson method of instruction associated with it. In terms of personal interest, the students indicated that the course's visual content and graphics could be used in everyday activities. The highest mode values for any grouping of statements in the study were found in the category of making sense of the information students learned in the course. The statements in this group also indicated that the information and processes taught in the course were viewed as a form of problem solving by students.

Many students see graphics education and visual skill development as a necessary basic in education, but difficult to learn. The researchers for this study concluded that students entering college understand that a difference exists between visual ability and visual skill and the need to increase their knowledge of visualization and communications. Students seemed comfortable using this knowledge to communicate technically and to visually problem-solve as well as understood the function of geometric constructions taught in the class. However, they also indicated they felt the need to have direct communication with the instructor and a need for high quality instruction. Overall, student's ratings in the category of attitudes, as indicated by the NCLAGES survey, concerning a fundamentals course in graphic communications was dominantly strongly agree.

\section{Future Research Recommendations}

The researchers recommend the following for future research in this area. First, because this is an adaptation of another instrument, extensive validation studies are needed for the NCLAGES survey. Second, other universities and colleges offering this type of course should administer the survey and compare their results so the outcomes can be examined. Third, this instrument and the data collected from it should be compared to data collected from other standard instruments that collect similar data. Fourth, an emphasis on using the data outside of the classroom needs to be expanded and emphasized in future studies. Fifth, students in graphics courses should be surveyed concerning their preferred formats of instruction (traditional lecture/laboratory, hybrid structure, or total distance education as learning environments). Since some students taking this 
survey were in hybrid course (on-line lectures and face-to-face laboratory), but the majority were in traditional lecture/laboratory, all formats of instruction were considered equal on all levels with student interest. Finally, the survey needs to be conducted on students in advanced graphics courses (i.e. animation, descriptive geometry, etc.). Information about student's attitudes in these courses will aid in the development of better and improved curricula for graphics education. In conclusion, this survey was conducted to identify the general attitudes students had about learning graphics as a general education requirement and their acceptance of the content presented. Although many in the courses came from traditional engineering fields, one can plainly see that graphics education needs to play a more important role in people's view of what constitutes an educated person and be more emphasized in disciplines other than engineering and technology. As society begins yet another century, curriculum and course developers in all fields need to see the importance visual skill development has on the future of our students and the education we provide them. The $21^{\text {st }}$ century is becoming the visual age, and our discipline is quickly becoming a new basic in general education.

\section{Bibliography}

1 Adams, W. K., Perkins, K. K., Podolefsky, N. S., Dubson, M., Finkelstein, N. D., \& Wieman, C. E. (2006). A new instrument for measuring student beliefs about physics and learning physics: The Colorado Learning Attitudes about Science Survey. Physical Review Special Topics: Physics Education Research, 2(1), 101-115.

2 Hein, T.L. \& Budny, D.D. (November, 1999). Teaching to students' learning styles: Approaches that work. Published Proceedings of the ASEE/IEEE Frontiers in Education Conference, San Juan, Puerto Rico, Session 12c1.

3 McIntosh, H., Berman, S.H. \& Youniss, J. (2007). An interim report on the evaluation of a comprehensive high school civic engagement intervention in Hudson, MA, Center for Information and Research on Civic Learning and Engagement (CIRCLE). 22-58.

4 Durik, A.M. \& Harackiewicz, J.M. (2007). Different strokes for different folks: how individual interest moderates the effects of situational factors on task interest. Journal of Educational Psychology, 99(3), 597-610.

5 Perkins, K. K., Adams, W. K., Pollock, S. J., Finkelstein, N. D., \& Wieman, C. E. (February, 2006). Correlating student beliefs with student learning using the Colorado Learning Attitudes about Science Survey. American Institute of Physics Conference Proceedings, 2004 Physics Education Research Conference 790, 61-64.

6 Perkins, K.K., Gratny, Adams, W.K., Finkelstein, N.D., \& Wieman, C.E. (February, 2006). Towards characterizing the relationship between students' interest in and their beliefs about physics. American Institute of Physics Conference Proceedings, 2005 Physics Education Research Conference 818, 137-140. 
7 Lieberman, D.A. \& Remedios, R. (2007). Do undergraduates' motives for studying change as they progress through their degrees?. British Journal of Educational Psychology, 77, 379-395.

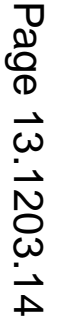

